\title{
Clinical Trial Ethics in the Era of COVID-19 Pandemic
}

\author{
Muhammet Arslan ${ }^{1^{*}}$, Nuket Ornek Buken ${ }^{2,3}$
}

${ }^{1}$ Hacettepe University, Faculty of Medicine, Department of Medical Ethics and History of Medicine, Turkey

${ }^{2}$ Head of Department, Hacettepe University Faculty of Medicine, Department of Medical Ethics and History of Medicine, Turkey

${ }^{3}$ Director of Hacettepe Center for Bioethics Hacettepe University Faculty of Medicine, Department of Medical Ethics and History of Medicine, Turkey

\section{Correspondence:}

Muhammet Arslan

Address: Hacettepe University, Faculty of Medicine, Department of Medical Ethics and History of Medicine, Turkey

Email:

muhammet.arslan@hacettepe.edu.tr

Received: 11.08.2020,

Accepted: 06.09.2020

https://doi.org/10.29333/jcei/9286

\begin{abstract}
The world has been suffering from the deadly effects of coronavirus and seemingly will continue to suffer for quite more time. Humanity has witnessed many kinds of outbreaks that have affected the population endemically or epidemically. Urgent need for treatment of COVID-19 is necessary and essential. In this article the cornerstones of clinical trial ethics, current publications and statements are analyzed to overcome the difficulties of pandemics with an additional focus on Turkey.
\end{abstract}

The researching physician, volunteering patients, industry, institutions, and national/international ethico-legal bodies are playing important role in clinical research. As stated in the Hippocratic Oath, it is a physician's duty to "first do no harm". Many international documents also state the fact that preserving the dignity of people and basic rights is the most essential attitude.

Clinical trials follow a certain set of principles regulated by legislative bodies. Medical ethics try to establish a common base for all research to fulfill the need for an internationally acceptable standard. Rather than serving the benefit of qualifications, ethical standards preserve qualitative values. It can be said that medical ethics is an appropriate discipline to serve the improvement of both science and morals.

Keywords: clinical trial ethics, COVID-19, research ethics, pandemics

\section{INTRODUCTION}

The world has been suffering from the deadly effects of coronavirus and seemingly will continue to suffer for quite more time. Throughout history, world has witnessed many kinds of outbreaks: Black Death, Cholera, Yellow Fewer, Polio, Flu (Spanish Flu, Swine Flu etc.), ZIKA, SARS, MERS, Ebola and many others have affected the population endemically or epidemically. It has always been important to be prepared for such conditions especially in terms of providing health services which play important roles in maintaining life and social interactions. Many experimental treatments and drugs have been tried and tested, yet, very few solutions for COVID-19 like pandemics have been found. For example, it is both saddening and unfortunate that the use of Malaria drugs (chloroquines) has been discussed during the Spanish flu pandemic and they are still being investigated in the chaos of today. Even though many warnings have been made on the matter of pandemics $[1,2]$, apparently very few of them are taken into account.

As of August 11, there are 20,319,063 total cases of coronavirus infected patients, and 740,352 deaths [3]. Health systems of many developed countries are in alarm situation. The world has been suffering from the lack of supplies, staff and essentials (masks, protective coats, ventilator etc.). Governments are announcing economic measurement packages for the brutal effects of the virus. Urgent need for treatment of COVID-19 is necessary and essential. All these facts undoubtedly highlight the importance of strict measures to be taken before, during and after the pandemics.

\section{CLINICAL TRIALS IN THE ERA OF COVID-19}

Basic research in the concept of medical development, animal experiments, experimental research and clinical trials are essential processes for the production of medical benefit. Their observable and systematic protocols are trustworthy sources 
in acquiring true and beneficial medical knowledge. Therefore, as they are dealing with humans, animals, sources and most importantly health, certain ethico-legal requirements also arise. Due to their delicate nature, ethical and legal aspects of medical research have been substantial. The ethico-legal framework of clinical research/trials become more important in situations like COVID-19 pandemic).

This is a time when the ethical and legal integrity of a clinical research is more problematic than any other time. There are primary and secondary parties who/which are ultimately concerned with the outcomes of research. The researching physician, volunteering patients, industry, institutions, and national/international ethico-legal bodies are playing important role in the process of clinical research. [4].

The researching physician deals with various aspects of clinical trials. Firstly, the physician has a fundamental duty to the discipline of medicine, to society and to the patient. Hereby, the physician has to fulfill the requirements of basic principles of ethics: beneficence, non-maleficence, justice and autonomy together with virtue, fidelity, equality, altruism and so on. Therefore, the physician deals with creating balance amongst all these principles which often tend to conflict in the times of pandemic. In this sense, the physician has responsibilities regarding the duty to treat and warn, end of life issues, dual relationships, scarce resources and confidentiality.

The volunteering patient possesses the obvious right to health and good service. Still, some compromises might be needed due to the unique nature of pandemic-like situations. Patients should be aware that all parties including themselves should be prudent and understanding not in terms of basic rights and needs but in their willingness to accept the use of alternatives and changes in protocols. Briefly, participants in clinical research have rights which they ought to expect, including the right to informed consent, shared decisionmaking, privacy for research participants, return of results and right to withdraw.

Industry and research institutions play substantial role in maintaining clinical trials, directly/indirectly production of new therapies, drugs and medical devices etc. Hence, they face economic and capital-related issues while they have to conserve and support the integrity of research.

There are 348,494 research studies in 216 countries registered on clinicaltrials.gov database as of 11.08.2020 [5]. According to a search on clinicaltrials.gov (using terms: COVID-19, 2019 novel coronavirus, 2019-ncov, SARSCov2, Severe Acute Respiratory Syndrome Coronavirus 2, Wuhan Coronavirus) total number of COVID-19 studies are 2965 (It was 997 in 29.04.2020) and increasing rapidly [5]. Only 274 of them were completed while most of them are still in recruiting. Highest number of studies about COVID-19 registered from Europe, Middle East, North America and
East Asia respectively [6]. Results evidently show that the need for clinical trials is essential and there is a growing appeal for COVID-19 studies.

\section{ETHICAL PERSPECTIVES ON CLINICAL TRIALS}

Traces of ethical codes in terms of clinical trials go back to ancient Greek. As stated in the Hippocratic Oath, it is a physician's duty to "first do no harm" (primum non nocere). Throughout history, variety of different declarations, guidelines and statements have been published [7].

One of the cornerstones of research ethics, the Nuremburg Code based on from the post-World War II Nuremberg war crimes trials, points out the basic principles when conducting research involving human subject. Thereafter codes structured the basis of further declarations and guidelines such as Declaration of Helsinki, Oviedo Convention and CIOMS Guidelines [8,9]. Codes also formed the basis for the globally accepted principle of informed consent where it is guaranteed. Accordingly, the participant must understand and accept the tenet to take part and must have the right to quit at any time.

Despite the global consensus on the "first do no harm" and "informed consent" principles, there have been some saddening examples of ethics in clinical trials (e.g. Tuskegee syphilis experiment). World Medical Association Declaration of Helsinki-Ethical Principles for Medical Research Involving Human Subjects as one of the most important documents on clinical trial ethics, lays the ground rules and principles for conducting a clinical trial. It was first published in 1964, Helsinki, Finland by World Medical Association and continues to be updated regularly. The declaration clearly highlights the importance of patients' well-being in connection with general ethical principles regardless of the possible benefits and outcomes.

"It is the duty of the physician to
promote and safeguard the health, well-
being and rights of patients, including
those who are involved in medical
research. The physician's knowledge
and conscience are dedicated to the
fulfilment of this duty."
"Medical research is subject to ethical
standards that promote and ensure
respect for all human subjects and
protect their health and rights." [10]

"Risks, burdens and benefits, vulnerable groups and individuals, scientific requirements and research protocols, research ethics committees, privacy and confidentiality, informed consent, use of placebo, post-trial provision, research registration and publication, dissemination of results and 
unproven interventions" are also mentioned in the declaration [10].

Declaration of Geneva, the so-called modern Hippocratic Oath, safeguards the ethical principles of the medical profession. Declaration also highlights the principle "first do no harm" and emphasizes the commitment for patients' health.

\section{"I solemnly pledge to consecrate my life to the service of humanity; \\ I will maintain the utmost respect for human life;" [11]}

Belmont Report created by National Commission for the Protection of Human Subjects of Biomedical and Behavioral Research published in 1979 summarizes the ethical principles for research involving human subjects [12]. It is stated that Belmont Report allowed subjects to make independent decisions which were not easy at the times by suggesting positive solutions [13]. Report mainly emphasizes the ethical principles respect for people, beneficence and justice thus it became one of the most essential guidelines on clinical research ethics.

International Ethical Guidelines for Biomedical Research Involving Human Subjects first published in 1982, updated and revisioned regularly by CIOMS (Council for International Organizations and Medical Sciences) provides international ethical principles and comments on how universal ethical principles should be applied.

\section{"Although scientific and social value are the fundamental justification for undertaking research, researchers, sponsors, research ethics committees and health authorities have a moral obligation to ensure that all research is carried out in ways that uphold human rights, and respect, protect, and are fair to study participants and the communities in which the research is conducted. Scientific and social value cannot legitimate subjecting study participants or host communities to mistreatment, or injustice." [14]}

The Universal Declaration of Human Rights is a universally accepted document adopted by United Nations General Assembly in 1948 [15]. The declaration mainly has a high opinion on individual human rights. Even though it doesn't state certain principles for clinical trial ethics, everyone's right to health and well-being is clearly stated in the document.
The Oviedo Convention (Convention for the Protection of Human Rights and Dignity of the Human Being with regard to the Application of Biology and Medicine: Convention on Human Rights and Biomedicine) as the first legally binding international text for preserving human dignity highlights principles about bioethics, medical research, consent, rights to private life and information, organ transplantation, public debate etc. The Convention's main doctrine is that the interests of individuals always come first, before the interests of society or science.

"Parties to this Convention shall protect
the dignity and identity of all human
beings and guarantee everyone, without
discrimination, respect for their
integrity and other rights and
fundamental freedoms with regard to
the application of biology and
medicine."
"Theinterestsandwelfare ofthehuman
being shall prevail over the sole interest
of societyor science."
"Any intervention in the health field,
including research, must be carried out
in accordance with relevant
professional obligations and
standards." [16]

All national and international texts state the need for ethical principles to preserve the dignity for all parties of a research. Regarding the current situation, many organizations share their guidelines concerning clinical trial ethics. These guidelines serve to enlighten the subjects of a research in troublesome of newly emerged pandemic. List of selected guidelines and their key points can be seen in Table 1.

EC, UNESCO, WHO, FDA and many other medical associations (American Medical Association, British Medical Association, Turkish Medical Association etc.) published guidelines and briefs on clinical trials to overcome the difficulties emerged during COVID-19. 
Clinical Trial Ethics in the Era of COVID-19 Pandemic

Table 1. List of Selected Guidelines on Clinical Research Ethics for COVID-19 Pandemic

\begin{tabular}{|c|c|c|c|}
\hline Institution & Title & Date & Key Points \\
\hline $\begin{array}{l}\text { European } \\
\text { Commission }(E C)^{1}\end{array}$ & $\begin{array}{l}\text { Guidance on The Management of Clinical Trials During } \\
\text { the COVID-19 (Coronavirus) Pandemic } \\
\text { Version } 1 \\
\text { Version 2: Key changes from v1 (20-03-2020): additional } \\
\text { clarification on obtaining informed consent; link to } \\
\text { methodological guidance on statistical considerations in } \\
\text { relation to COVID-19 pandemic; advice on IMP stocks, } \\
\text { safety reporting, conduct of audits; temporary halts } \\
\text { Version 3: Key changes from v2 (27-03-2020): distributor } \\
\text { to trial participant IMP shipment, monitoring, remote } \\
\text { source data verification and communication with } \\
\text { authorities }\end{array}$ & 28.04 .2020 & $\begin{array}{l}\text { - Initiating New Trials/Changes to Ongoing Trials } \\
\text { - Safety Reporting/Risk Assessment } \\
\text { - Communication with Authorities } \\
\text { - Communication Between Sponsors, Trial Sites and Trial Participants } \\
\text { - Changes to Informed Consent } \\
\text { - Changes in the Distribution of The Investigational Medicinal Products } \\
\text { - Changes in the Distribution of In Vitro Diagnostic and Medical } \\
\text { - Cevices } \\
\text { - Changes to Monitoring/Changes to Auditing } \\
\text { - Reimbursement of Exceptional Expenses } \\
\text { - Initiation of New Trials Aiming to Test New Treatments for Covid-19 } \\
\text { - Annex 1: Protection of Trial Participants' Rights During Remote } \\
\text { Source Data Verification }\end{array}$ \\
\hline $\begin{array}{l}\text { United Nations } \\
\text { Educational, } \\
\text { Scientific and } \\
\text { Cultural } \\
\text { Organization } \\
(\text { UNESCO) }\end{array}$ & $\begin{array}{l}\text { Statement on COVID-19: ethical considerations from a } \\
\text { global perspective }\end{array}$ & 06.04 .2020 & $\begin{array}{l}\text { - Health and Social Policies } \\
\text { - Sound Scientific Knowledge and Practices } \\
\text { - Weaknesses of the Healthcare Systems } \\
\text { - Allocation of Resources } \\
\text { - Patient Triage } \\
\text { - Vulnerable Individuals } \\
\text { - Right to Health/Duty to Health } \\
\text { - Access to Timely, Accurate, Clear, Complete, and Transparent } \\
\text { - Information } \\
\text { - Responsible Research Practices } \\
\text { - Effective Use of Digital Technologies } \\
\text { - International Collaboration } \\
\text { - Dependency Between the Countries } \\
\text { - Solidarity }\end{array}$ \\
\hline $\begin{array}{l}\text { WHO (World } \\
\text { Health } \\
\text { Organization) }\end{array}$ & $\begin{array}{l}\text { Clinical management of severe acute respiratory } \\
\text { infection when novel coronavirus (2019-nCoV) } \\
\text { infection is suspected: Interim Guidance }\end{array}$ & 28.01 .2020 & $\begin{array}{l}\text { - Triage } \\
\text { - Appropriate Infection Prevention and Control Measures } \\
\text { - Early Supportive Therapy and Monitoring } \\
\text { - Collection of Specimens for Laboratory Diagnosis } \\
\text { - Management of Hypoxemic Respiratory Failure and Acute } \\
\text { Respiratory Distress Syndrome (ARDS) } \\
\text { - Management of Septic Shock } \\
\text { - Prevention of Complications } \\
\text { - Specific Anti-Ncov Treatments } \\
\text { - Special Considerations for Pregnant Patients }\end{array}$ \\
\hline $\mathrm{WHO}^{4}$ & Off-label use of medicines for COVID-19: Scientific Brief & 31.03 .2020 & $\begin{array}{l}\text { - Solidarity Trial } \\
\text { - Subjection to National Laws and Regulations } \\
\text { - Stockpiling } \\
\text { - Creation of Shortages for Approved Medicines } \\
\text { - Informed Consent } \\
\text { - Monitorization/Documentation/Publication of Changes in Protocol } \\
\text { - Compliance with National and International Laws }\end{array}$ \\
\hline $\begin{array}{l}\text { FDA (Food and } \\
\text { Drug } \\
\text { Administration) }\end{array}$ & $\begin{array}{l}\text { FDA Guidance on Conduct of Clinical Trials of Medical } \\
\text { Products during the COVID-19 Public Health Emergency }\end{array}$ & $\begin{array}{l}\text { Last update: } \\
02.07 .2020 \\
\text { First } \\
\text { published: } \\
\text { March, } 2020\end{array}$ & $\begin{array}{l}\text { - Suspension or Continuation of an Ongoing Study } \\
\text { - Initiation of a New Study } \\
\text { - Administering or Using an Investigational Product } \\
\text { - Management of Protocol Deviations and Amendments } \\
\text { - Initiation of Virtual Clinical Trials } \\
\text { - Management of Deviations to Address Patient Safety } \\
\text { - Switches to Home Deliveries } \\
\text { - Switches to Home Infusion } \\
\text { - Delays to On-Site Monitorings } \\
\text { - Difficulties of Obtaining Informed Consent } \\
\text { - Implementation Remote Performance Outcome (Perfo) Assessments } \\
\text { - } \text { or Interview-Based Clinician-Reported Outcome (Clinro) Assessments } \\
\text { - Remote Monitoring Visits } \\
\text { - Selection of Alternate Laboratories or Imaging Facilities } \\
\text { - Postmarket Device Studies }\end{array}$ \\
\hline
\end{tabular}

${ }^{1}$ https://ec.europa.eu/health/sites/health/files/files/eudralex/vol-10/guidanceclinicaltrials_covid19_en.pdf Access Date: 11.08.2020.

${ }^{2}$ https://unesdoc.unesco.org/ark:/48223/pf0000373115 Access Date: 11.08.2020.

${ }^{3}$ https://www.who.int/publications-detail/clinical-management-of-severe-acute-respiratory-infection-when-novel-coronavirus-(ncov)-infection-issuspected Access Date: 11.08.2020.

${ }^{4} \mathrm{https}$ //www.who.int/news-room/commentaries/detail/off-label-use-of-medicines-for-covid-19 Access Date: 11.08.2020.

${ }^{5}$ https://www.fda.gov/regulatory-information/search-fda-guidance-documents/fda-guidance-conduct-clinical-trials-medical-products-during-covid-19public-health-emergency Access Date: 11.08.2020. 
Clinical Trial Ethics in the Era of COVID-19 Pandemic

Table 2. List of Selected Guidelines on Clinical Trial Ethics in Turkey for COVID-19 Pandemic

\begin{tabular}{|c|c|c|c|}
\hline Institution & Title & Date & Key Points \\
\hline $\begin{array}{l}\text { TiTCK (Turkey } \\
\text { Pharmaceuticals and } \\
\text { Medical Devices } \\
\text { Agency) }^{6}\end{array}$ & $\begin{array}{l}\text { Precautions to be Taken in Clinical Researches Due to } \\
\text { COVID-19 Pandemic }\end{array}$ & 19.03 .2020 & $\begin{array}{l}\text { - } \text { Early or Temporary Termination } \\
\text { - } \text { Emergency Security Measures } \\
\text { - } \text { Protocol Deviations } \\
\text { - } \text { Monitorization } \\
\text { - Supplementation of Research Materials } \\
\text { - } \text { Laboratory and Diagnostic Services } \\
\text { - Visits } \\
\text { - } \text { Changes in Research Center and Staff } \\
\text { - } \text { Researcher Meetings } \\
\text { - } \text { Ethics Comming } \\
\text { - Increase in Volunteers } \\
\text { - Evaluation Periods }\end{array}$ \\
\hline TітCK $^{7}$ & $\begin{array}{l}\text { Treatment Approaches for COVID-19 Patients and } \\
\text { Scientific Studies }\end{array}$ & 16.04 .2020 & $\begin{array}{l}\text { - } \text { Off-label Drug Use } \\
\text { - } \text { Drug Supply } \\
\text { - Informed Consent } \\
\text { - } \text { Adverse Reactions } \\
\text { - } \text { Requirements for Clinical Research } \\
\text { - } \text { Alternative Approaches in Treatment } \\
\text { - } \text { Ethics Committees } \\
\text { - } \text { Monitorization }\end{array}$ \\
\hline TітCK $^{8}$ & Scientific Research Evaluation Commission & 28.04 .2020 & $\begin{array}{l}\text { - Initiation and Publication of Research } \\
\text { - } \quad \text { Application for Ethics Committees } \\
\text { - } \quad \text { Application to Scientific Research Evaluation Commission }\end{array}$ \\
\hline $\begin{array}{l}\text { TTB (Turkish Medical } \\
\text { Association)9 }\end{array}$ & TTB Ethics Committee's Opinion on Outbreaks & 04.04 .2020 & $\begin{array}{l}\text { - } \text { Management of Epidemics } \\
\text { - } \text { Privacy } \\
\text { - } \text { Discrimination and Stigmatization } \\
\text { - } \text { Rulnerable Groups } \\
\text { - } \text { International Cooperation } \\
\text { - Surveillance/Role of Media } \\
\text { - Limits of Duty to Service } \\
\text { - } \quad \text { Allocation of Resources } \\
\text { - } \quad \text { Triage } \\
\text { - } \text { Pressure on Health Professionals } \\
\text { - Scientific Studies }\end{array}$ \\
\hline
\end{tabular}

\section{CLINICAL TRIAL ETHICS IN TURKEY DURING}

Due to its cosmopolitan base of ethnicity, disease burden, incidence of genetic and rare diseases, Turkey possesses an important capacity for clinical trials [17]. It is placed $28^{\text {th }}$ in most number of clinical trials according to the WHO database [18]. Turkey ranked as Tier 3 in pharmerging markets list together with Indonesia, Thailand, Mexico, Egypt, Vietnam and South Africa [19].

As compliant with EU (European Union) directives, Turkey strictly follows international treaties and bindings. Basic human rights and freedoms are always prioritized before national laws and regulations. Turkish legislation on clinical trials is in compliance with Good Clinical Practices (ICH GCP), directives of EU, Helsinki Declaration, Oviedo Convention and other binding documents. In that sense, it is proven that Turkey decisively follows international standards.

Participation in a clinical trial is on voluntary basis, without any incentives to the participant. Each clinical trial needs an approval of an independent Ethics Committee and permission of the Ministry of Health. All trials have to have voluntarily obtained informed consent of the participant.

According to clinicaltrials.gov, 84 coronavirus studies have been registered from Turkey as of August 11, 2020 [20]. Turkey has also taken strict measures during the days of COVID-19. Guidelines have been published for the management of clinical trials. TITTCK (Turkey Pharmaceuticals and Medical Devices Agency) is the responsible authority and legislates in the relevant matter. TTB (Turkish Medical Association) is the representing institution of Turkish physicians. Both these institutions published guidelines on the management of clinical trials during COVID-19 (See Table 2). The documents are coherent with international criteria. Their main objective as the protection of human rights and freedom is emphasized. They prioritize the dignity of participants and research; the benefit of the individual is always precedenced than the benefits of society.

\footnotetext{
${ }^{6}$ https://titck.gov.tr/storage/Archive/2020/announcement/8ca5ea8c-4933-446c-acd5-de9384385f03.pdf Access Date: 11.08.2020.

${ }^{7}$ https://www.titck.gov.tr/mevzuat/covid-19-hastalarinda-tedavi-yaklasimlari-ve-bilimsel-arastirmalar-konulu-genelge-16042020172320 Access Date: 11.08.2020.

${ }^{8} \mathrm{https} / /$ drive.google.com/file/d/1ggnGlcvIQA6GSixmmzllg6eOZ080KusS/view? usp=sharing Access Date: 11.08.2020.

${ }^{9}$ https://www.ttb.org.tr/makale_goster.php?Guid=4da9a49c-7674-11ea-b329-aa051764b049 Access Date: 11.08.2020.
} 


\section{FORESIGHTS AND DISCUSSION}

Pandemics have affected the world throughout history and will continue to be seen for as long as pathogens exist. Being prepared and foresighted for such situations is the most essential part. As COVID-19 pandemic reminded again, regardless of developments in science, possibilities and chances of a new mutation will always try to strike us from many forgotten and not yet discovered perspectives.

Dealing with the deadly effects of a pandemic, human dignity, morals, beneficence, justice, autonomy, virtue and many other concepts have increased in importance. We have come to understand the fundamental need for ethical and legal standards to be set beforehand to deal with chaotic situations. Society cumulatively should be in engagement with all parts of living together. Governments should take precautions and measures in terms of allocation of limited resources, services and goods. Attempts on national and international level to overcome any possible crisis should be made. Scientific community should focus more on improving the stamina to fight with fatal diseases. Health professionals should be aware of the importance of their work and efforts. The public should behave in accordance with precautions and measures.

As stated in many international documents, preserving the dignity of people and basic rights is the most essential attitude to have. Due to the challenging nature of pandemics, clinical trials are exposed to many difficulties especially in fulfilling ethical requirements.

In conclusion, a good acceptable research has almost the same factors to be ethically acceptable too. Clinical trials follow a certain set of principles regulated by legislative bodies. Medical ethics try to establish a common base for all research to fulfill the need for an internationally acceptable standard. Rather than serving the benefit of qualifications, ethical standards preserve qualitative values. It can be said that medical ethics is an appropriate discipline to serve the improvement of both science and morals.

Declaration of interest: The authors report no conflicts of interest.

Financial Disclosure: No financial support was received.

\section{REFERENCES}

1. Taubenberger JK, Morens DM. 1918 Influenza: The mother of all pandemics. Emerg Infect Dis. 2006; 12(1): 15-22. doi:10.3201/eid1209.05-0979.

2. Horimoto T, Kawaoka Y. Influenza: Lessons from past pandemics, warnings from current incidents. Nat Rev Microbiol. 2005; 3(8): 591-600. doi: 10.1038/nrmicro1208

3. Worldometer. Coronavirus Cases. 2020. Available at: https:/www.worldometers.info/coronavirus/coronavir us-cases/\#daily-cases (Accessed: 11 August 2020).
4. Büken NÖ. Clinical trial ethics in Turkey in the context of some expectations and predictions. Int J Clin Trials. 2016; 3(4): 180. doi: 10.18203/2349-3259.ijct20163954.

5. Clinicaltrials.gov. Home-ClinicalTrials.Gov. 2020. Available at: https://clinicaltrials.gov/ (Accessed: 11 August 2020).

6. Clinicaltrials.gov. Trends, Charts, and Maps ClinicalTrials.gov. 2020. Available at: https://clinicaltrials.gov/ct2/resources/trends\#Locations OfRegisteredStudies (Accessed: 11 August 2020).

7. Büken N, Büken E. The legal grounds regarding clinical trial in Turkey. Med Law. 2011; 30(4): 591-611.

8. Dhai A. The research ethics evolution: From Nuremberg to Helsinki. S Afr Med J. 2014; 104(3): 178-180. doi: 10.7196/SAMJ.7864.

9. Annas GJ. The changing landscape of human experimentation: Nuremberg, Helsinki, and beyond. Health Matrix Clevel. 1992; 2: 119.

10. World Medical Association. WMA Declaration of Helsinki-Ethical Principles for Scientific Requirements and Research Protocols. World Medical Association. 2013. Available at: https://www.wma.net/policiespost/wma-declaration-of-helsinki-ethical-principlesfor-medical-research-involving-human-subjects/ (Accessed: 20 May 2020).

11. World Medical Association. WMA Declaration of Geneva. World Medical Association. 1948. Available at: https://www.wma.net/policies-post/wma-declarationof-geneva/ (Accessed: 11 August 2020).

12. Sims JM. A brief review of the Belmont Report. Dimens Crit Care Nurs. 2010; 29(4): 173-4. doi: 10.1097/DCC.0b013e3181de9ec5.

13. Vollmer SH, Howard G. Statistical Power, the Belmont Report, and the Ethics of Clinical Trials. Sci Eng Ethics. 2010; 16(4): 675-91. doi: 10.1007/s11948-010-9244-0.

14. CIOMS. International Ethical Guidelines for Healthrelated Research Involving Humans. Council for International Organizations of Medical Sciences. Geneva: 2016. Available at: https://cioms.ch/wpcontent/uploads/2017/01/WEB-CIOMS-

EthicalGuidelines.pdf (Accessed: 11 August 2020).

15. Zandy J. Universal declaration of human rights. Radic Teach. 2019; 113: 54-5. doi: 10.5195/rt.2019.591.

16. Council of Europe. Oviedo Convention. Convention on Human Rights and Biomedicine. Available at: https://www.coe.int/en/web/conventions/full-list//conventions/treaty/164 (Accessed: 11 August 2020).

17. Büken N. Opinions about the future of Clinical Trial in Turkey. J Clin Exp Investig. 2017; 7(3): 258-64. doi: 10.5799/jcei.328618.

18. World Health Organization. Monitoring processes to R\&D. WHO. 2020. Available at: https://www.who.int/ research-observatory/monitoring/processes/clinical_ trials_2/en (Accessed: 11 August 2020.). 
19. Doughman E. 'Pharmerging' Markets Expected to Lead Healthcare Growth - Pharmaceutical Processing World. 2019. Available at: https://www.pharmaceutical processingworld.com/pharmerging-markets-expectedto-lead-healthcare-growth/ (Accessed: 11 August 2020).
20. Clinicaltrials.gov. Search of: COVID-19 - List Results ClinicalTrials.gov. Available at: https://clinicaltrials.gov/ ct $2 /$ results $/$ details?cond $=$ COVID-19\&term $=\&$ cntry $=$ TR $\&$ state $=\&$ city $=\&$ dist $=\&$ Search $=$ Search $\quad$ (Accessed: 11 August 2020). 